\title{
Editorial
}

\section{The infant airway}

This edition of the Canadian Journal of Anaesthesia contains an interesting case report ${ }^{1}$ of the anaesthetic management of a neonate with a prenatally diagnosed upper airway obstruction due to a cervical cystic hygroma. Although the obstetrical management may raise questions and deserves separate comment, I will restrict this editorial to the paediatric airway. All presentations, articles and chapters on the paediatric airway start with a litany of the differences between the infant airway and that of the older child and adults. ${ }^{2-4}$ These include a large head and short neck, the narrow nares, the large tongue, the high glottis, the slanting vocal cords, and the narrow epiglottis which is angled away from the axis of the trachea. At first glance this seems a formidable list of potential difficulties. In practice, there is less than meets the eye in the normal newborn. The difficulty in intubation lies entirely with the size of the mandible. If it is smaller than normal as one finds with Pierre Robin, Treacher Collins and other micrognathic syndromes, intubation may well be difficult, although as the child grows older intubation problems associated with micrognathia diminish. In contrast to the micrognathic syndromes, abnormalities involving the cervical spine, e.g., Klippel-Feil syndrome and connective tissue mucopolysaccharides (Hurler, Scheie, Hunter and Morquio syndromes), do not present severe difficulties in intubation until the second half of the first decade. If the mandible is normal size, intubation in other carniofacial defects, e.g., cleft lip and palate, Crouzon and Apert syndromes, will not present a problem as long as an induction with intravenous agents and muscle relaxants is chosen and not an inhalational one.

The truth is that a majority of intubation problems arise because most anaesthetists normally use a curved MacIntosh blade for intubation. The manual habit patterns which are ingrained for the use of the curved blade are the opposite to those which are required for the straight blade normally employed for infants and children less than seven years of age. How often does one find a resident, on first being exposed to the paediatric patient, supinate his right hand and, grasping the crown of the

From the Department of Anaesthesia, Hospital for Sick Children, 555 University Ave., Toronto, Ontario, M5G 1 X8.

\section{R.E. Creighton MD FRCPC}

head between thumb and index finger, extend the neck and thereby raise the larynx to an anterior position. Then, the right index finger is placed in the right side of the patient's mouth, forcing the laryngoscope in the left hand to be placed over the tongue. Further, by hauling back on the laryngoscope blade, the angle of the blade is changed to an incorrect position parallel to the operating table. Finally, a request is made that posterior pressure be applied to the larynx. The "resident" has made every possible mistake and changed a routine intubation in an infant into an adventure. First, the head should be placed in a head ring so that it adopts the position of "a bird dog on point" with the shoulders held posteriorly on the operating table top. The head should be in a neutral position with the neck neither flexed nor extended. The straight blade of the laryngoscope should be placed in the right hand corner of the mouth lateral to the tongue and positioned, for the most part, at right angles to the table top slightly medial and slightly caudal. The route to the larynx from the base of the tongue forms a much more acute angle in the infant than in the older child and adult and, unless the blade is placed lateral to the tongue, exposure of the glottis will be very difficult.

Identifying the patient in whom the trachea will be difficult to intubate is usually easy if the mandible is small. Abnormalities of the ear or presence of ear tags which develop, in common with the mandible, from the first and second branchial arches may be a sign that intubation will be difficult. In other instances, prediction is no less difficult than it is in adults. Latto and Rosen describe a prospective study of 1200 patients in which difficult intubation was anticipated in 84 patients, but in only 22 was it actually difficult. However, in a further 21 patients intubation turned out to be difficult. Experience with the paediatric airway suggests that it is similar.

Tanaka et $a l^{1}{ }^{1}$ have presented an algorithm for the management of the difficult airway. Because of the particular problems associated with their case presentation, the algorithm is complex. For the usual paediatric patient I would suggest the algorithm described in Figure 1. If the head is correctly positioned and the laryngoscope is correctly placed, in most cases a portion of the lower laryngeal inlet of the glottis will become visible if the laryngoscopist applies posterior pressure over the larynx with his own index and middle finger. When one con- 
siders the angle between the base of the tongue and the glottic opening, it is obvious that it is much easier to move the glottic opening posterior and therefore into line with the straight laryngoscope blade than it is to try to iron out the angle between the base of the tongue and the glottic opening by raising the laryngoscope blade to a position more parallel to the table top. Once a portion of the glottis is exposed, an assistant or nurse can be relied upon to pass the endotracheal tube through the vocal cords.

Many of the tricks, e.g., blind nasal intubation, light wand, retrograde insertion of a wire through the cricothyroid membrane, etc., which anaesthetists have relied upon in the past have been superseded by the small fibreoptic flexible bronchoscope. It is now available in a diameter as small as $2.2 \mathrm{~mm}$ and has greatly facilitated intubation where the larynx cannot be visualized by conventional means. Although not essential, these instruments are more readily positioned if the patient is allowed to continue breathing spontaneously.

In the final analysis, if intubation proves difficult and specialized equipment and experienced assistance are not available, it is preferable to discontinue anaesthesia, allow the patient to wake up, and defer surgery until they can be obtained. If they cannot be made available, the patient should be referred to a centre where they are.

\section{Les voies aériennes supérieures de l'enfant}

Dans ce numéro du Journal Canadien d'Anesthésie, on rapporte un cas intéressant d'obstruction des voies aériennes supérieures chez un nouveau-né ${ }^{1}$ et la conduite anesthésique qui fut adoptée. La cause de l'obstruction était un hygroma cervical kystique diagnostiqué avant la naissance. Bien que la conduite obstétricale puisse en elle-même susciter des questions et commentaires, cet éditorial traitera uniquement des voies aériennes pédiatriques. Lorsque ce sujet fait l'objet dune communication dans une réunion, d'un article ou d'un chapitre de volume, la mode est toujours de décliner les différences qui existent entre les voies aériennes du nourrisson et celles des enfants plus âgés et des adultes. ${ }^{2-4}$ Ces différences comprennent la grosseur relative de la tête et la brièveté du cou, le rétrécissement des narines, le volume de la langue, la surélévation de la glotte, linclinaison des cordes vocales, l'étroitesse de l'épiglotte et l'angle qui l'éloigne de l'axe de la trachée. A première vue, ces caractéristiques représentent une accumulation redoutable d'obstacles. En pratique, chez le nouveau-né normal, ce n'est pas si compliqué que cela. La difficulté de l'intubation vient entièrement de la taille du maxillaire inférieur. Dans le syndrome de Pierre Robin, de Treacher Collins et autres micrognathies, le maxillaire est plus petit que la normale, ce qui augmente les difficultés de l'intubation. Mais à mesure que l'enfant grandit, les difficultés causées par la micrognathie s'estompent. Contrairement aux syndromes caractérisés par la micrognathie, les anomalies de la colonne cervicale, comme le syndrome de KlippelFeil, les mucopolysaccharidoses (syndromes de Hurler, Scheie, Hunter et Morquio) ne présentent de réels problèmes d'intubation qu'à partir de la seconde moitié de la première décennie. Si la mâchoire est normale, lintubation en présence d'autres anomalies cranio-faciales comme le bec de lièvre et la fente palatine, des syndromes de Crouzon et d'Apert n'occasionnent pas de difficultés en autant qu'on choisira une induction intraveineuse avec myorelaxants plutôt qu'une induction par inhalation.

En réalité, il n'est pas facile pour les anesthésistes d'intuber avec la lame courbée de MacIntosh. Cet entêtement pour la lame courbe va à l'encontre de la logique; on aurait tout intérêt à utiliser la lame droite pour les enfants de sept ans ou moins. Lors du premier contact avec un nourrisson, il n'est pas rare de voir le résident tourner la paume de sa main droite vers le haut, saisir la tête entre son index et son pouce, forcer l'extension du cou, ce qui amène le larynx en position antérieure. Il introduit par la suite son index droit dans le coin droit de la bouche et appuie le laryngoscope sur la langue avec sa main gauche. Avec la traction vers le bas de la lame du laryngoscope, l'angle devient parallèle à la table d'opération, position désavantageuse pour l'intubation. Finalement, il demande d'appliquer une pression sur le larynx vers le bas. Le "résident " a fait toutes les erreurs imaginables et c'est à ce moment qu'une intubation facile devient périlleuse. D'abord la tête devrait être placée dans un anneau et les épaules maintenues postérieurement sur la table d'opération. La tête doit être en position neutre sans flexion ni extension du cou. La lame droite du laryngoscope doit être introduite au coin droit de la bouche, latéralement à la langue, et dirigée à angle droit avec la table, légèrement vers le centre et en direction caudale. A partir de la base de la langue, le passage au larynx forme un angle beaucoup plus aigu chez le nourrisson que chez l'adulte et à moins que la lame ne soit dirigée latéralement à la langue, l'exposition de la glotte sera très difficile.

Lorsque le maxillaire inférieur est petit, il est facile de prédire que la trachée sera difficile à intuber. Ceci est vrai aussi en présence d'anomalies de l'oreille qui, 
comme le maxillaire, se développe à partir du premier et du deuxième arc branchial. Dans une étude prospective de 1200 patients, Latto et Rosen ont anticipé 84 intubations difficiles, mais en réalité seulement 22 des enfants furent difficiles à intuber. Cependant chez 21 autres patients, l'intubation fut laborieuse. L'expérience suggère que c'est bien là la réalité.

Tanaka et al. ${ }^{1}$ décrivent un organigramme décisionnel en prévision des difficultés d'intubation. Les problèmes suscités par le cas quills présentent étant spéciaux, cet organigramme ne peut être que complexe. Pour le patient pédiatrique ordinaire, je suggère l'organigramme décrit à la Figure 1. Avec la tête en bonne position et l'insertion correcte du laryngoscope, une partie de la commissure postérieure du larynx sera visible la plupart du temps, si le laryngoscopiste exerce une pression sur le larynx avec son index et son médius. Si on tient compte de l'angle de la base de la langue avec l'ouverture de la glotte, il est évident qu'il est plus facile de déplacer l'ouverture glottique postérieurement et donc de la situer en ligne avec la lame droite du laryngoscope que d'essayer d'aplanir l'angle entre la base de la langue et l'ouverture glottique en soulevant la lame du laryngoscope vers une position plus parallèle à la table. Une fois une partie de la glotte exposée, on peut demander à un assistant de pousser le tube endotrachéal à travers les cordes vocales.

Le bronchoscope flexible à fibres optiques a surclassé les stratagèmes auxquels les anesthésistes ont eu recours pendant des années comme l'intubation nasale à l'aveugle, le mandrin lumineux et l'insertion rétrograde à travers la membrane cricothyroïdienne. Il est maintenant disponible en diamètres aussi petits que $2,2 \mathrm{~mm}$ et facilite grandement l'intubation lorsque les moyens conventionnels sont dépassés. Bien que ce ne soit pas essentiel, on peut manipuler plus aisément cet appareil en respiration spontanée.

Finalement, si l'intubation s'avère difficile, qu'une instrumentation spécialisée et une assistance expérimentée sont introuvables, il est préférable de mettre fin à l'anesthésie, éveiller le patient et reporter la chirurgie jusqu’à ce que ces conditions se réalisent. En cas d'impossibilité, il faut transférer le patient dans un centre hospitalier prêt à faire face à ce genre de difficultés.

\section{References}

1 Tanaka M, Sato $S$, Naito $H$, Nakayama $H$. Anaesthetic management of a neonate with prenatally diagnosed cervical tumour and upper airway obstruction. Can J Anaesth 1994; 41: 236-40.

2 Stewart DJ (Ed.). Manual of Pediatric Anesthesia, 3rd ed. New York: Churchill Livingstone Inc., 1990.

3 Berry FA (Ed.). Anaesthetic Management of Difficult and
Routine Pediatric Patients, 2nd ed. New York: Churchill Livingstone Inc., 1990.

4 Coté $C J(E d$.$) . A Practice of Anesthesia for Infants and$ Children. Philadelphia: W.B. Saunders Co., 1992.

5 Latto IP, Rosen $M$ (Eds.). Difficulties in Intubation. London: Ballière Tindall, 1987. 